\title{
Experimental colitis in mice is attenuated by topical administration of chlorogenic acid
}

\author{
Hubert Zatorski • Maciej Salaga • Marta Zielińska • Aleksandra Piechota-Polańczyk • \\ Katarzyna Owczarek • Radzislaw Kordek • Urszula Lewandowska • Chunqiu Chen • \\ Jakub Fichna
}

Received: 12 November 2014 / Accepted: 22 February 2015 / Published online: 7 March 2015

(C) The Author(s) 2015. This article is published with open access at Springerlink.com

\begin{abstract}
Epidemiological data suggest that the consumption of polyphenol-rich foods reduces the incidence of cancer, coronary heart disease, and inflammation. Chlorogenic acid (CGA), an ester of caffeic and quinic acids, is one of the most abundant polyphenol compounds in human diet with proven biological effectiveness both in vitro and in vivo. The aim of the study is to investigate the possible anti-inflammatory effect of CGA in the gastrointestinal (GI) tract and its mechanism of action. We used a well-established model of colitis, induced by intracolonic (i.c.) administration of trinitrobenzenesulfonic acid (TNBS) in mice. The antiinflammatory effect of CGA in the colon was evaluated based on the clinical and macroscopic and microscopic parameters. To investigate the mechanism of protective action of CGA, myeloperoxidase (MPO), $\mathrm{H}_{2} \mathrm{O}_{2}$, and NF- $\mathrm{kB}$ levels were assessed in the colon tissue. CGA administered i.c. at the dose of $20 \mathrm{mg} / \mathrm{kg}$ (two times daily) protected against TNBSinduced colitis more effectively than the same dose administered orally (p.o.), as evidenced by significantly lower macroscopic and ulcer scores. Furthermore, CGA $(20 \mathrm{mg} / \mathrm{kg}$, i.c.) reduced neutrophil infiltration, as demonstrated by decreased MPO activity. Moreover, CGA suppressed activation of $\mathrm{NF}-\mathrm{KB}$, as evidenced by lower levels of phospho-NF- $\mathrm{kB} /$
\end{abstract}

\footnotetext{
H. Zatorski - M. Sałaga • M. Zielińska · A. Piechota-Polańczyk •

K. Owczarek $\cdot$ U. Lewandowska J. Fichna $(\bowtie)$

Department of Biochemistry, Faculty of Medicine, Medical

University of Lodz, Mazowiecka 6/8, 92-215 Lodz, Poland

e-mail: jakub.fichna@umed.lodz.pl

C. Chen

Department of Gastroenterological Surgery, Tenth People's Hospital of Shanghai, School of Medicine, Tongji University,

Shanghai, China

R. Kordek

Department of Pathology, Faculty of Medicine, Medical University of Lodz, Lodz, Poland
}

NF- $\mathrm{KB}$ ratio in the tissue. CGA did not affect the oxidative stress pathways. CGA exhibits anti-inflammatory properties through reduction of neutrophil infiltration and inhibition of NF-kB-dependent pathways. Our results suggest that CGA may have the potential to become a valuable supplement in the treatment of GI diseases.

Keywords Chlorogenic acid - Trinitrobenzenesulfonic acid - Experimental colitis - Inflammatory bowel diseases . Crohn's disease · Ulcerative colitis

\section{Introduction}

Inflammatory bowel diseases (IBDs), which include Crohn's disease (CD) and ulcerative colitis (UC), are chronic, relapsing inflammatory disorders of the gastrointestinal (GI) tract. Whereas the inflammation in UC affects only colonic mucosa, in $\mathrm{CD}$, it affects the entire gut wall and may occur in any part of the GI tract (Podolsky 2002). Currently, the incidence and prevalence of IBD are the highest in westernized nations (Molodecky et al. 2012). However, considering that the incidence of IBD is increasing, mortality is low, and the disease is most often diagnosed in the young people, the prevalence of IBD will continue to increase globally (Molodecky et al. 2012). Treatment with 5-aminosalicylates, immunosuppressive agents, glucocorticosteroids, and biological therapies are generally effective in IBD. However, the side effects and economic costs, especially with biological therapy, cannot be ignored. These facts, together with impaired patients' quality of life, imply that new therapeutics are needed.

The etiology of IBD remains largely unknown, but it is considered to be related to a combination of genetic, microbi$\mathrm{al}$, immunological, and environmental factors that results in an inordinate and abnormal immune response in genetically 
vulnerable individuals. Recent studies highlight that both innate and adaptive immune responses maintain the same importance in development of gut inflammation (Zhang and $\mathrm{Li}$ 2014). However, apart from the presence of activated innate immune response cells, such as macrophages, neutrophils, and monocytes, an excessive production of reactive oxygen species (ROS) and pro-inflammatory mediators, including TNF- $\alpha$ and interleukin (IL)-1, -6 , and -8 , plays a major role in the pathogenesis of IBD (Babior 2000; Sun et al. 2013). Of note, natural immunity, and also most types of inflammation, is mediated by transcription nuclear factor $\kappa \mathrm{B}(\mathrm{NF}-\kappa \mathrm{B})$-related pathways (Umezawa 2011). It has been shown that NF- $\kappa B$ is strongly activated in patients with IBD, as well as in experimental models of colitis (Atreya et al. 2008).

Chlorogenic acid (CGA), formed by esterification of caffeic and quinic acids (Fig. 1), is one of the most abundant polyphenols in nature (Suzuki et al. 2006). CGA widely occurs in medicinal plants from Europe and Asia, for example, honeysuckle, Angelicae sinensis Radix, and Chuanxiong Rhizoma, as well as in coffee beans and apples (Hebeda et al. 2011; Hulme 1953; Li et al. 2014a, b). Several studies were conducted to investigate biological activities of CGA, including its anti-bacterial, anti-carcinogenic, and antioxidant effects in animal models of diseases (Kim et al. 2010; Lafay et al. 2006; Ruifeng et al. 2014); however, the effect of CGA on the inflammatory reaction in the GI tract has not been explored so far.

In search for novel therapeutics and supplements for treatment of GI diseases, here we characterized the antiinflammatory action of CGA in experimental colitis in mice. In particular, we were interested in the effect of CGA after disparate routes of administration, as well as the involvement of NF-кB-regulated pathways. The animal model of colitis used in our experiments, induced by intracolonic (i.c.) administration of 2,4,6-trinitrobenzenesulfonic acid (TNBS), has

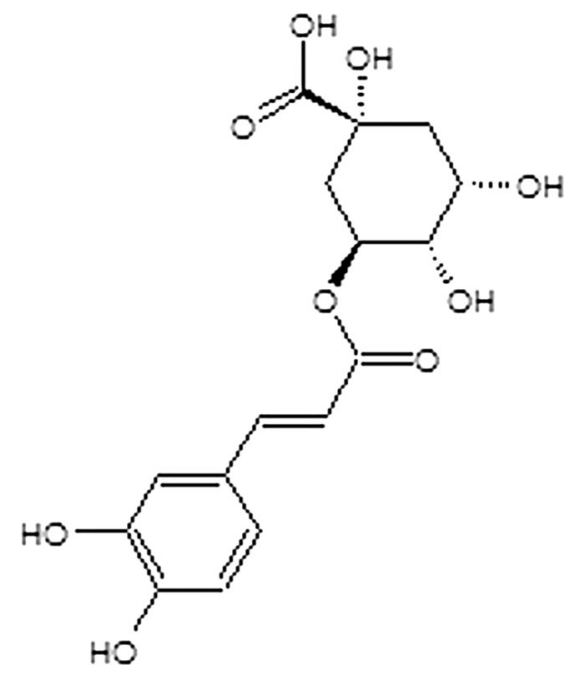

Fig. 1 Chemical structure of CGA been chosen for this study because it closely mimics clinical and morphological features of human CD (Elson et al. 1995).

\section{Materials and methods}

Animals

Male balbC mice were obtained from the Animal House at the University of Lodz, Poland. All animals, weighing 22-28 g, were housed at a constant temperature $\left(22^{\circ} \mathrm{C}\right)$ and maintained under a 12-h light/dark cycle in sawdust-lined plastic cages with free access to chow and tap water. All animal protocols were approved by the Medical University of Lodz Animal Care Committee (Protocol \#670/2012).

Induction of colitis

Colitis was induced by i.c. administration of TNBS, as described previously (Storr et al. 2009). Briefly, mice were lightly anesthetized with $1 \%$ isoflurane (Baxter Healthcare Corp., IL, USA) and TNBS (4 mg in $0.1 \mathrm{~mL}$ of $30 \%$ ethanol in saline) was administered into the colon through a catheter inserted $3 \mathrm{~cm}$ proximally to the anus. Previous experiments showed that the dose of TNBS used in this study induced reproducible colitis.

\section{Pharmacological treatment}

CGA was administered two times daily at the dose of $20 \mathrm{mg} / \mathrm{kg}$ orally (p.o., $150 \mu \mathrm{L})$ and i.c. $(100 \mu \mathrm{L})$, with the first treatment $30 \mathrm{~min}$ before the induction of colitis in acute colitis model. In semi-chronic colitis model, CGA was administered two times daily at the dose of $20 \mathrm{mg} / \mathrm{kg}$ i.c. $(100 \mu \mathrm{L})$ from day 3 to day 6. CGA was dissolved in $5 \%$ dimethyl sulfoxide (DMSO) in saline, which was used as vehicle. Control animals received vehicle alone. Briefly, mice were lightly anesthetized with $1 \%$ isoflurane (Baxter Healthcare Corp., IL, USA) and CGA was administered into colon through a catheter inserted $3 \mathrm{~cm}$ proximally to the anus.

Evaluation of colonic damage

Animals were killed by cervical dislocation 3 days after TNBS application in acute colitis model and 7 days post-TNBS in semi chronic colitis model. Colons were instantly removed, opened longitudinally, washed with phosphate-buffered saline (PBS), and immediately examined. Macroscopic colonic damage was assessed using an established semi-quantitative scoring system by adding individual scores for ulcer, colonic shortening, wall thickness, and presence of hemorrhage, fecal blood, and diarrhea, as described previously (Fichna et al. 2012; Sałaga et al. 2013, 2014b). For ulcer score and colonic 
shortening, the following scale was used: ulcer, 0.5 points for each $0.5 \mathrm{~cm}$; shortening of the colon, 1 point for $>15 \%$ and 2 points for $>25 \%$ (based on the mean length of the colon in untreated mice of $8.07 \pm 0.20 \mathrm{~cm}, n=6$ ). The wall thickness was measured in millimeters with vernier caliper, and thickness of $n$ in mm corresponds to $n$ scoring points. The presence of hemorrhage, fecal blood, or diarrhea increased the score by 1 point for each additional feature. The macroscopic scoring was performed in blind manner.

\section{Histology}

After macroscopic scoring, segments of the distal colon were stapled flat, mucosal side up, onto cardboard and fixed in $10 \%$ neutral-buffered formalin for $24 \mathrm{~h}$ at $4{ }^{\circ} \mathrm{C}$. Samples were then dehydrated, embedded in paraffin, sectioned at $5 \mu \mathrm{m}$, and mounted onto slides. Subsequently, sections were stained with hematoxylin and eosin and examined using a Motic AE31 microscope (Ted Pella, Redding, CA, USA). Photographs were taken using a digital imaging system consisting of a digital camera (Moticam 2300, Ted Pella, Redding, CA, USA) and image analysis software (MoticImages Plus 2.0, Motic Deutschland GmbH, Wetzlar Germany). Microscopic total damage score was determined in blind manner based on the presence $($ score $=1)$ or absence $($ score $=0)$ of goblet cell depletion, the presence $($ score $=1)$ or absence $($ score $=0)$ of crypt abscesses, the destruction of mucosal architecture (normal $=1$, moderate $=2$, extensive $=3$ ), the extent of muscle thickening (normal $=1$, moderate $=2$, extensive $=3$ ), and the presence and degree of cellular infiltration (normal $=1$, moderate $=2$, transmural $=3$ ).

Determination of tissue myeloperoxidase activity

The method adapted by Fichna et al. (2012) was used to assess granulocyte infiltration and to quantify the myeloperoxidase (MPO) activity. Shortly, 1-cm segments of colon were weighed and homogenized in hexadecytrimethylammonium bromide (HTAB) buffer (0.5\% HTAB in $50 \mathrm{mM}$ potassium phosphate buffer, $\mathrm{pH} 6.0 ; 50 \mathrm{mg}$ tissue $/ \mathrm{mL}$ ) immediately after isolation. Homogenate was centrifuged (15 min, 13,200 rpm, $4{ }^{\circ} \mathrm{C}$ ), and $7 \mu \mathrm{L}$ of supernatant was added to each well on a 96-well plate, containing $200 \mu \mathrm{L}$ of $50 \mathrm{mM}$ potassium phosphate buffer ( $\mathrm{pH}$ 6.0), supplemented with $0.167 \mathrm{mg} / \mathrm{mL}$ of $\mathrm{O}$-dianisidine hydrochloride and $0.05 \mu \mathrm{L}$ of $1 \% \mathrm{H}_{2} \mathrm{O}_{2}$. Absorbance was measured at $450 \mathrm{~nm}$ (iMARK Microplate Reader, Biorad, Hemel Hempstead, Hertfordshire, UK). All measurements were performed in triplicate. MPO was expressed in milliunits per gram of wet tissue, 1 unit being the quantity of enzyme able to convert $1 \mu \mathrm{mol}$ of $\mathrm{H}_{2} \mathrm{O}_{2}$ to water in $1 \mathrm{~min}$ at room temperature. Units of MPO activity per 1 min were calculated from a standard curve using purified peroxidase enzyme.

Determination of tissue hydrogen peroxide levels

Assay was performed according to the methodology described before by Sałaga et al. (2014a).

Briefly, $50 \mathrm{mg}$ of colon tissue fragments was homogenized with $2 \mathrm{~mL}$ of $1.15 \%$ potassium chloride. Then, $10-\mu \mathrm{L}$ aliquots of tissue homogenate were mixed with $90 \mu \mathrm{L}$ of PBS (pH 7.0) and $100 \mu \mathrm{L}$ of horseradish peroxidase $(1 \mathrm{U} / \mathrm{mL})$ containing $400 \mu \mathrm{mol}$ homovanilic acid (HRP+HVA assay) or with $90 \mu \mathrm{L}$ of PBS and $100 \mu \mathrm{L}$ of $1 \mathrm{U} / \mathrm{mL}$ horseradish peroxidase only (HRP assay). Both homogenates were incubated for $60 \mathrm{~min}$ at $37{ }^{\circ} \mathrm{C}$. Subsequently, $300 \mu \mathrm{L}$ of PBS and $125 \mu \mathrm{L}$ of $0.1 \mathrm{M}$ glycine- $\mathrm{NaOH}$ buffer (pH 12.0) with $25 \mathrm{mM}$ EDTA were added to each homogenate sample. Excitation was set at $312 \mathrm{~nm}$ and emission was measured at $420 \mathrm{~nm}$ (PerkinElmer Luminescence Spectrometer, Beaconsfield, UK). Readings were converted into $\mathrm{H}_{2} \mathrm{O}_{2}$ concentration using the regression equation $Y=0.012 X-0.007$, where $Y=\mathrm{H}_{2} \mathrm{O}_{2}$ concentration in homogenate $(\mu \mathrm{M})$ and $X=$ intensity of light emission at $420 \mathrm{~nm}$ for HRP+HVA assay reduced by HRP assay emission (arbitrary units, AU). The regression equation was prepared from three series of calibration experiments with 10 increasing $\mathrm{H}_{2} \mathrm{O}_{2}$ concentrations (range 10-1000 $\mu \mathrm{M}$ ). The lowest $\mathrm{H}_{2} \mathrm{O}_{2}$ detection was $0.1 \mathrm{nM}$, with intra-assay variability not exceeding a $2 \%$.

Western blot analysis of NF-kB protein levels

Shortly, the tissue was minced and homogenized with the use of a motor-driven Potter homogenizer in 10 volumes of lysis buffer. Concentration of total protein pool was evaluated in each sample using modified Lowry protocol (Cadman et al. 1979). Separation of proteins $(30 \mu \mathrm{g} / \mathrm{well})$ was performed on $7.5 \%$ SDS-PAGE gel in electrophoretic buffer. Electrophoretically separated proteins were electroblotted using Immobilon $\mathrm{P}$ membranes (pore size, $0.45 \mu \mathrm{m})$ in transfer buffer. The membranes were incubated for $1 \mathrm{~h}$ at room temperature in $3 \%$ non-fat dry milk Tris-buffered saline with Tween $20(0.05 \%)$ to saturate non-specific protein binding sites (Stawinska et al. 2008). The membranes were probed with the following primary antibodies (Santa Cruz Biotechnology, Paso Robles, CA, USA) overnight at $4{ }^{\circ} \mathrm{C}$ : anti-rabbit anti-mouse p65 $(1: 4000)$ and pp65 (1:5000) and $\beta$-GAPDH (1:3000) as reference protein. Appropriate horseradish-peroxidase- 
conjugated secondary antibodies were applied for $1 \mathrm{~h}$ at room temperature, and then the bands were visualized using a $3,3^{\prime}, 5,5^{\prime}-12$ tetramethylbenzidine (TMB) as a substrate for the localization of HRP activity. Qualitative and quantitative analysis was performed by measuring integrated optical density (OD) by GelProAnalyzer ver. 3.0 for Windows $^{\mathrm{TM}}$ program (Media Cybernetics, Warrendale, PA, USA).

\section{Drugs}

All drugs and reagents, unless otherwise stated, were purchased from Sigma-Aldrich (Poznan, Poland). CGA (purity $98 \%$ by high-performance liquid chromatography) was extracted from honeysuckle flowers and purchased from Nanjing Zelang Medical Technology Co. (Nanjing, Jiangsu, China) by one of the authors (C.C.). In all in vivo tests, drugs were dissolved in $5 \%$ DMSO in saline, which was used as vehicle in control groups. Vehicle affected none of the measured parameters when given alone.

\section{Statistics}

Statistical analysis was performed using Prism 5.0 (GraphPad Software Inc., La Jolla, CA, USA). The data are expressed as means \pm SEM. One-way ANOVA followed by Newman-
Keuls post hoc test was used for analysis. $P$ values $<0.05$ were considered statistically significant.

\section{Results}

Intracolonic administration of CGA attenuates acute TNBS-induced colitis in mice

The i.c. instillation of TNBS caused reproducible colitis in mice, characterized by elevated macroscopic colon damage score and increased MPO activity. The i.c. administration of CGA (20 mg/kg, two times daily) significantly attenuated acute TNBS-induced colitis, as demonstrated by decreased total macroscopic score $(2.16 \pm 0.27$ vs. $3.77 \pm 0.50$ for CGA+TNBS- and TNBS-treated mice, respectively) (Fig. 2a). Moreover, CGA significantly reduced ulcer score $(0.29 \pm 0.09$ vs. $0.79 \pm 0.19$ for CGA+TNBS- and TNBStreated mice, respectively) (Fig. 2b) and increased mouse colon length compared with TNBS-treated animals (Fig. 2c). Colon thickness and MPO activity were reduced by i.c. administration of CGA, but the differences did not reach statistical significance (Fig. 2d, e, respectively). Histological evaluation of colon damage revealed that i.c. CGA significantly reduced the microscopic score (Fig. 3). Administration of

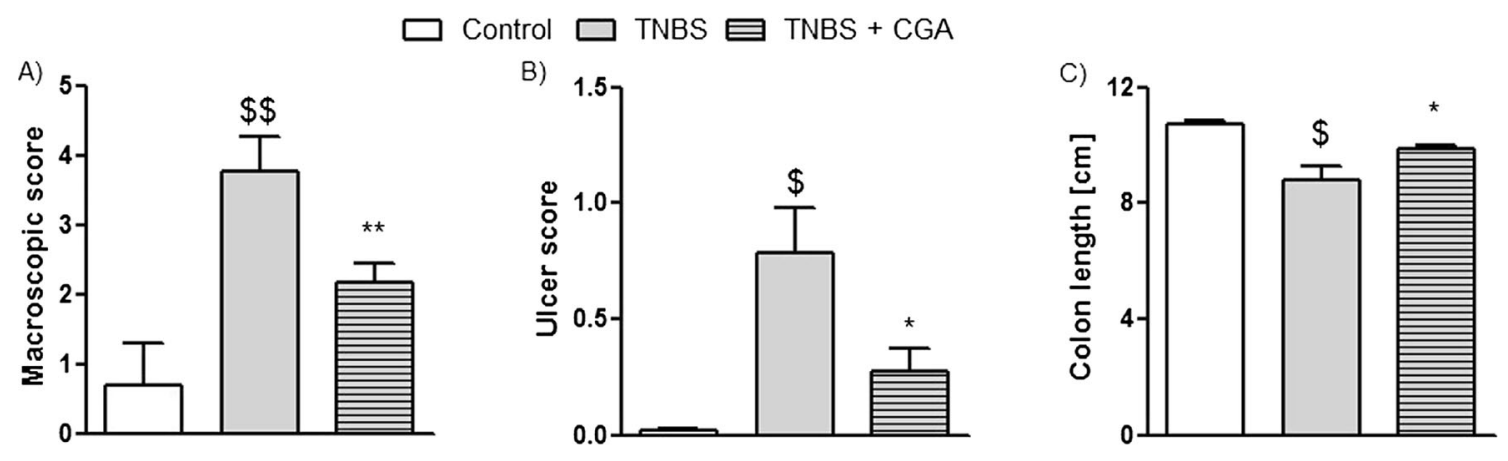

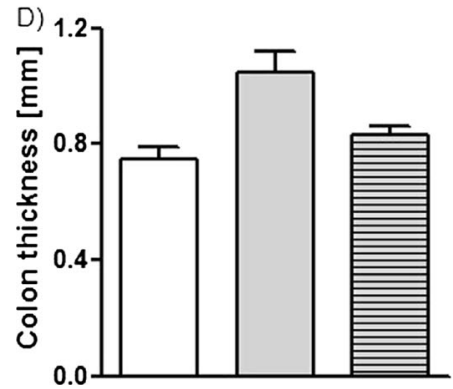

Fig. 2 CGA $(20 \mathrm{mg} / \mathrm{kg})$ injected two times daily i.c. over 3 days attenuated TNBS-induced colitis in mice. Shown are data for macroscopic scores (a), ulcers score (b), colon length (c), colon thickness (d), and MPO activity (e) after i.c. administration. ${ }^{\$} P<0.05,{ }^{\$} P<0.01$, as

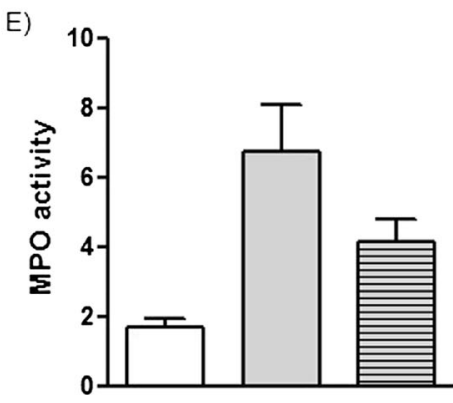

compared to control (vehicle treated) mice; ${ }^{*} P<0.05$, ${ }^{* *} P<0.01$, as compared to TNBS-treated animals. Data represent mean \pm SEM of 7-12 mice per group 


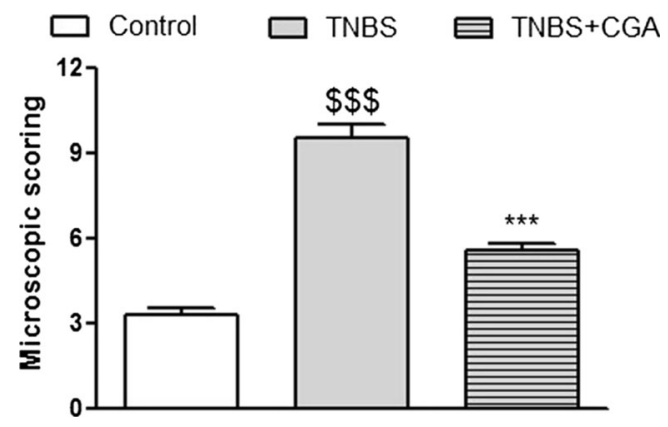

Fig. 3 Microscopic total damage score were attenuated by injection of CGA $\left(20 \mathrm{mg} / \mathrm{kg}\right.$, two times daily, i.c.). ${ }^{\$ \$} P<0.001$, as compared to control (vehicle-treated) mice; $* * * P<0.001$ as compared to TNBStreated animals. Data represent mean \pm SEM of 7-12 mice per group

CGA in dose of $20 \mathrm{mg} / \mathrm{kg}$ i.c. had no effect on studied parameters in control mice.

CGA administered p.o. has anti-inflammatory effect on acute TNBS-induced colitis in mice

Oral administration of CGA attenuated acute TNBS-induced colitis in mice, but the effect was weaker than that observed after i.c. instillation (macroscopic score, $2.82 \pm 0.3$ vs. $2.16 \pm$ 0.27 for p.o. and i.c. CGA, respectively, Figs. $4 \mathrm{a}$ and 2a; ulcer score, $0.63 \pm 0.15$ vs. $0.28 \pm 0.09$ for p.o. and i.c. CGA, respectively, Figs. $4 \mathrm{~b}$ and $2 \mathrm{~b})$. Furthermore, CGA ( $20 \mathrm{mg} / \mathrm{kg}$, p.o., two times daily) did not have any significant effect on colon length (Fig. 4c), colon thickness (Fig. 4d), and MPO activity

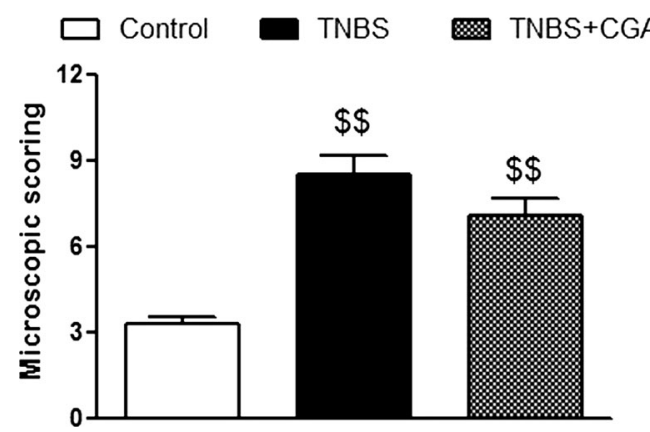

Fig. 5 CGA $(20 \mathrm{mg} / \mathrm{kg})$ injected two times daily p.o. over 3 days attenuated TNBS-induced colitis in mice. Shown are data from microscopic total damage score. ${ }^{\$} P<0.01$, as compared to control (vehicletreated) mice. Data represent mean \pm SEM of 7-12 mice per group

(Fig. 4e) in TNBS-treated mice. In addition, p.o. administration of CGA did not attenuate microscopic score (Fig. 5). Administration of CGA in dose of $20 \mathrm{mg} / \mathrm{kg}$ p.o. had no effect on studied parameters in control mice.

Intracolonic administration of CGA attenuates established TNBS-induced colitis in mice

The i.c. administration of CGA ( $20 \mathrm{mg} / \mathrm{kg}$, two times daily) significantly attenuated established colonic inflammation in the model of TNBS-induced colitis, as demonstrated by decreased total macroscopic score ( $1.78 \pm 0.28$ vs. $5.94 \pm 0.67$ for CGA+TNBS- and TNBS-treated mice, respectively) (Fig. 6a).

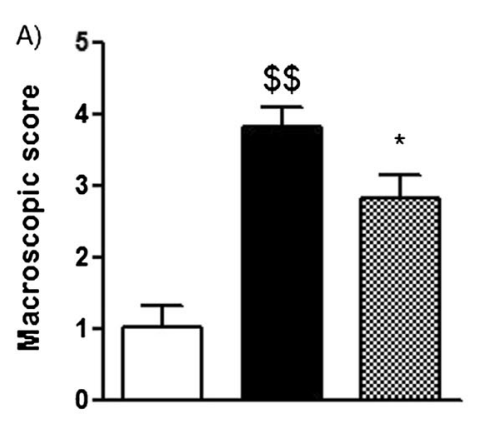

Control

B)
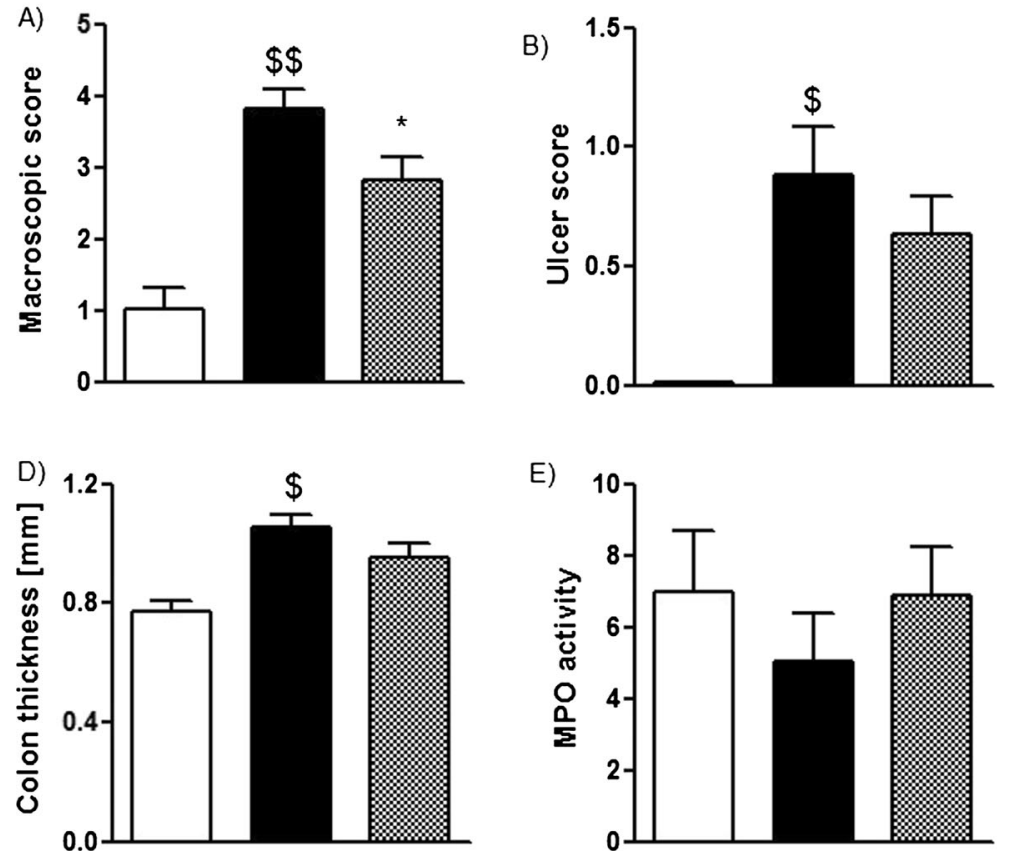

E)

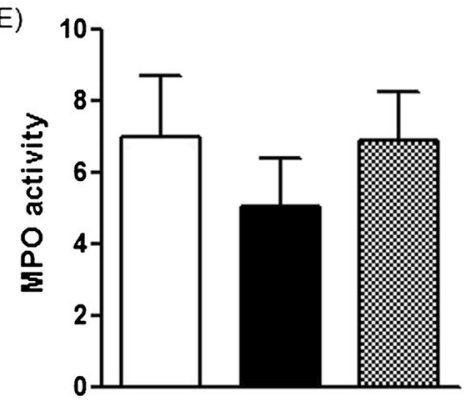

Fig. 4 CGA (20 mg/kg) injected two times daily p.o. over 3 days attenuated TNBS-induced colitis in mice. Shown are data for macroscopic score (a), ulcer score (b), colon length (c), colon thickness (d), and
MPO activity (e). ${ }^{\$} P<0.05,{ }^{\$} P<0.01$, as compared to control (vehicletreated) mice; $* P<0.05$, as compared to TNBS-treated animals. Data represent mean $\pm \mathrm{SEM}$ of $7-12$ mice per group 

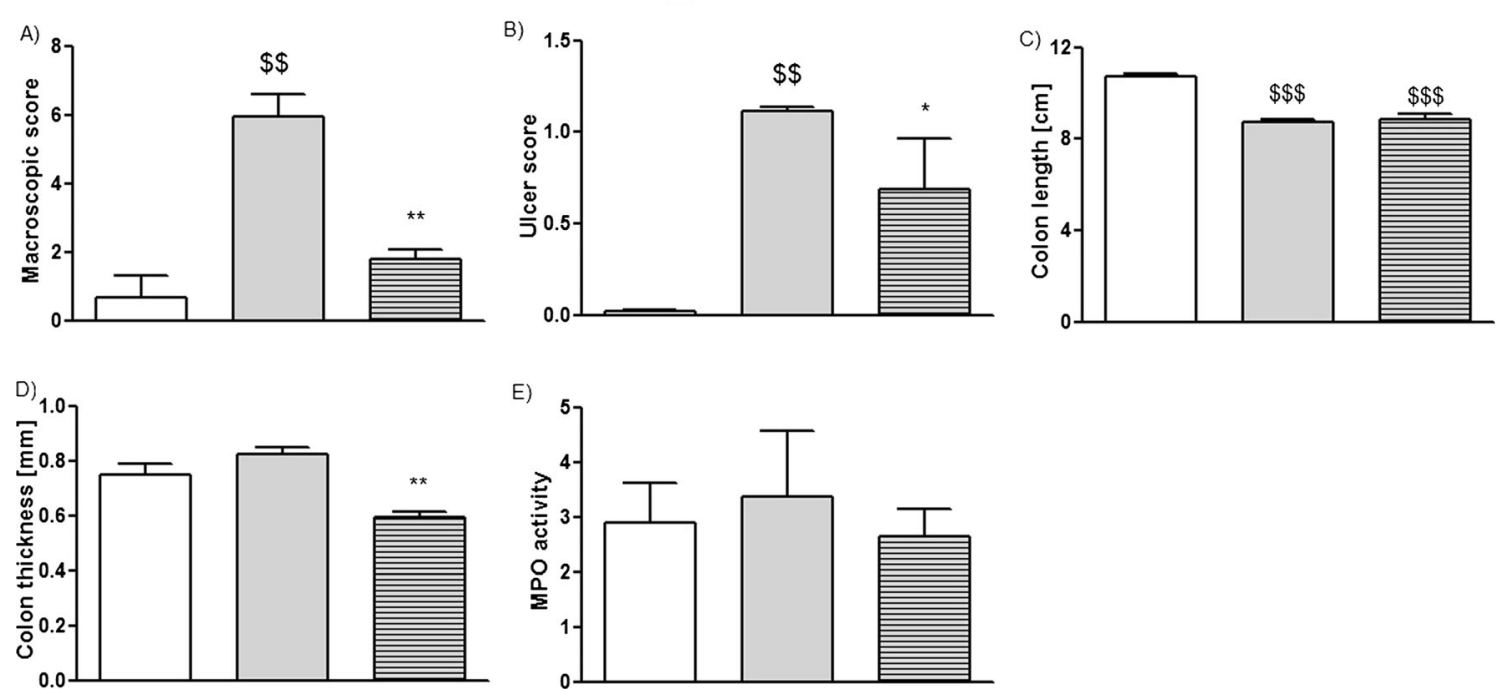

Fig. 6 CGA $(20 \mathrm{mg} / \mathrm{kg})$ injected two times daily i.c. over 5 days attenuated established TNBS-induced colitis in mice. Shown are data for macroscopic score (a), ulcer score (b), colon length (c), colon thickness (d), and MPO activity (e). ${ }^{\$} P<0.01,{ }^{\$ \$} P<0.001$ as compared to

Moreover, CGA significantly reduced ulcer score $(0.69 \pm 0.27$ vs. $1.12 \pm 0.02$ for CGA+TNBS- and TNBS-treated mice, respectively) (Fig. 6b) and decreased mouse colon thickness compared with TNBS-treated animals (Fig. 6d). However, CGA had no effect on colon length (Fig. 6c). Furthermore, MPO activity was slightly reduced, but the difference did not reach statistical significance (Fig. 6e).

CGA administered i.c. did not affect hydrogen peroxide level in acute TNBS-induced colitis

As shown in Fig. 7, there was an increase in $\mathrm{H}_{2} \mathrm{O}_{2}$ level measured in the colon of TNBS-treated mice versus control (vehicle treated) animals. The i.c. administration of CGA had no effect on tissue $\mathrm{H}_{2} \mathrm{O}_{2}$ level in TNBS-induced colitis $(0.51 \pm$ 0.11 vs. $0.63 \pm 0.28$ for CGA+TNBS- and TNBS-treated mice, respectively).

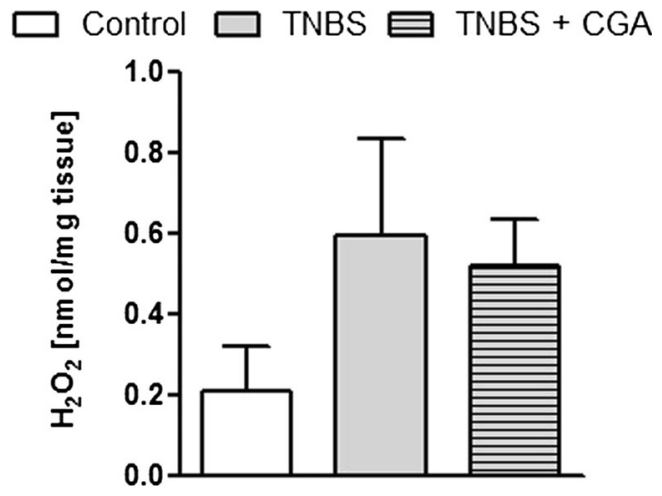

Fig. 7 The effect of CGA ( $20 \mathrm{mg} / \mathrm{kg}$, i.c., two times daily) on hydrogen peroxide levels in TNBS-treated mice. Data represent mean \pm SEM of 7 12 mice per group

control (vehicle-treated) mice; $* P<0.05, * * P<0.01$ as compared to TNBS-treated animals. Data represent mean \pm SEM of 7-12 mice per group

CGA administered i.c. reduced activated NF-KB levels

The i.c. administration of CGA significantly decreased phospho-p65/p-65 ratio in the colon tissue $(0.19 \pm 0.01$ vs. $0.82 \pm 0.16$ for CGA+TNBS- and TNBS-treated mice, respectively) (Fig. 8).

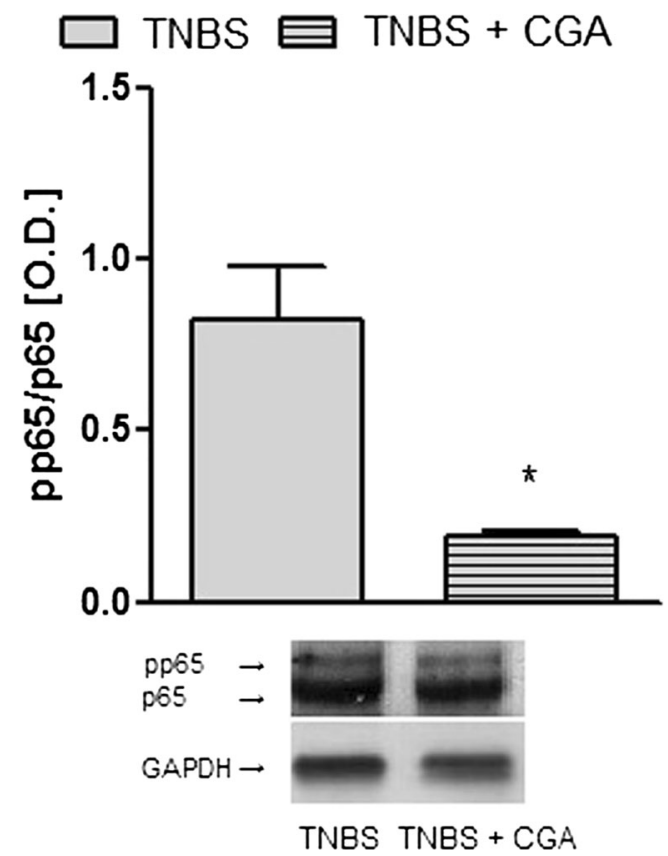

Fig. 8 CGA (20 mg/kg, i.c., two times daily) significantly decreased phospho-p65/p-65 ratio in the mouse colon tissue. The upper panel shows results of quantitative analysis and the lower panel shows a representative blot for protein expression of phosphop65 and p65 in TNBS- and TNBS+CGA-treated mice. $* P<0.05$, as compared to TNBS-treated animals. Data represent mean \pm SEM of 6-8 mice per group 


\section{Discussion}

Comprehensive data in the literature show that polyphenols possess anti-oxidant, anti-carcinogenic, and antiinflammatory properties, of which only the first two were sufficiently explored. CGA, which is one of the most abundant natural polyphenols, has been proven as a potent antioxidant and anti-cancerogenic agent, both in the in vivo and in vitro studies, but only a few reports focused on its antiinflammatory activity in vivo. Hence, the primary goal of this study was to evaluate the anti-inflammatory effect of CGA and to investigate the potential mechanism of its action in the GI tract.

We showed that CGA displayed a significant antiinflammatory activity in a well-established mouse model of experimental colitis, as evidenced by reduction of macroscopic damage score, MPO activity, and inhibition of NF- $\mathrm{kB}$ activation. We also demonstrated that CGA produced antiinflammatory effect regardless of the oxidative-stress-related pathways. Our study, along with previously published reports, shows that CGA may become a new therapeutic or an attractive supplement in the treatment of IBD. Furthermore, we showed that the i.c. administration of CGA not only alleviates colitis in the acute phase but also has healing effects on established TNBS-induced colonic inflammation. This indicates that CGA may have both prophylactic and therapeutic activity and may be used in patients regardless of the current stage of the disease. Moreover, the literature data support our observations showing that also other quinic acid derivatives alleviate chronic colitis (di Paola et al. 2010).

Of note, in a study performed by $\mathrm{Ng}$ et al. (2014), consumption of coffee had a protective effect against UC development in Asians (adjusted OR 0.51; $95 \%$ CI 0.36 to 0.72 ; group of $256 \mathrm{UC}$ patients diagnosed between 2011 and 2013 from eight countries in Asia and Australia vs. 940 controls). Furthermore, the average intake of coffee by Americans is 3.1 cups a day; moreover, a single serving of coffee provides between 20 and $675 \mathrm{mg}$ of CGA depending on type of roast and the volume consumed (Del Rio et al. 2010). Thus, the dose of CGA used in this study corresponds to the average intake consumed by human while drinking coffee.

Noteworthy, we found that CGA is more effective after i.c. than p.o. administration in the mouse model of colitis, which speaks for its topical, rather than systemic, application. CGA is absorbed in its intact form in the stomach and - as products of hydrolysis, such as caffeic acid-in the small intestine. Once in the cecum, CGA is fully hydrolyzed into caffeic and other aromatic acids (Lafay et al. 2006), with questionable biologic activity. This in turn results in lower concentration of CGA in inflamed colonic tissue after p.o.- than i.c.-administration, which may be the reason for its weaker antiinflammatory action.
Immunocyte recruitment and activation are key steps in the intestinal innate immune response (Korzenik et al. 2005; Kucharzik et al. 2001; Reaves et al. 2001), and studies with animal models of colitis highlight the relationship between immunocyte infiltration and disease severity (Knutson et al. 2013). Here we observed that CGA impaired neutrophil recruitment and protected colonic tissue against injury, as evidenced by decreased MPO activity, in line with earlier studies showing a profound effect of CGA on immune cells. For example, Ruifeng et al. (2014) demonstrated that CGA ameliorates damage of mammary tissues by reducing neutrophil infiltration. It was also shown that CGA inhibits proinflammatory cytokine release induced by lipopolysaccharide (LPS) in RAW264.7 murine macrophage-like cells (Shan et al. 2009), as well as leukocyte influx and levels of IL-4, IL-5, and TNF- $\alpha$ in serum and bronchoalveolar lavage fluid in endotoxin and allergic lung inflammation (Zhang et al. 2010). A critical point in neutrophil migration is their ability to adhere to endothelial surface and transfer to inflamed tissues by means of over-expressed or activated adhesion molecules. A key role in this process is played by L-selectin located on neutrophils, along with P- and E-selectin on endothelium. A recent study conducted by Hebeda et al. (2011) indicates that CGA treatment blocks L-selectin shedding induced by LPS in neutrophils obtained from rat peritoneum. Moreover, in that study, the treatment with CGA inhibited LPS-induced platelet endothelial cell adhesion molecule 1 (PECAM-1) expression on neutrophil membranes. Our data suggest that the antiinflammatory effect of CGA in the GI tract may also result from interaction with post-transcriptional mechanisms of adhesion molecule expression (Hebeda et al. 2011).

$\mathrm{NF}-\mathrm{kB}$ is a key transcription factor involved in promoting the formation of pro-inflammatory mediators. It is a heterodimer consisting of Rel-family proteins including p65, cRel, RelB, p50, and p52 (Hoesel and Schmid 2013). Although $\mathrm{NF}-\kappa \mathrm{B}$ is indispensable for maintaining immune functions, its excessive activation leads to stimulation of immune cells, resulting in inflammation ( $\mathrm{Li}$ and Verma 2002). Activation of NF- $\kappa \mathrm{B}$ involves phosphorylation of an inhibitory protein I $\mathrm{B}$, which binds to NF- $\mathrm{B}$, followed by liberation of activated factor, its entry to the nucleus, and binding to the $\mathrm{kB}$ site in DNA (Umezawa 2011). In this study, we investigated the NF- $\kappa$ B activity by assessing pp65/p65 ratio from colonic tissue homogenates. We found that TNBS caused a significant activation of NF- $\mathrm{KB}$, as shown by higher pp65/p65 ratio, which was decreased after CGA treatment. Our observation is in line with the study by di Paola et al. (2010), in which a quinic acid derivative, 3,5-dicaffeoyl-4-maloquinic acid, administered orally reduced MPO levels and inhibited NF-KB activity in experimental colitis induced by i.c. instillation of dinitrobenzenesulphonic acid (DNBS) in rats. In another, in vitro study, the extract from Cymbopogon citrates, containing CGA reduced TNF- $\alpha$ levels and NF- $\kappa$ B activity in human 
macrophages in a monocyte culture (Francisco et al. 2013). Taken together, our study is in line with a growing body of evidence showing that CGA has impact on various types of immune cells via NF-KB-dependent pathways. CGA may thus be used to restore the function of the imbalanced immune system, including GI inflammation.

The molecular mechanism of CGA action in alleviating experimental colitis still requires further research. Recently, oxidative stress and imbalanced production of free oxygen species have been implicated in IBD pathogenesis. Oxidative stress may lead to DNA damage, apoptosis, and cancer development (Valko et al. 2001, 2007). There are several anti-oxidative mechanisms in the GI tract, which include enzymes like catalase (CAT), superoxide dismutase (SOD), and glutathione peroxidase (GPx), along with non-enzymatic scavengers, such as glutathione, transient ions (e.g., $\mathrm{Fe}^{2+}$ ), or flavonoids. SOD catalyses the reduction of $\mathrm{O}_{2}^{-}$to $\mathrm{H}_{2} \mathrm{O}_{2}$. In normal cell metabolism, $\mathrm{H}_{2} \mathrm{O}_{2}$ is further reduced by GPx in the presence of NADPH, but during inflammation, when concentration of $\mathrm{H}_{2} \mathrm{O}_{2}$ increases, it is reduced by CAT. Recent studies suggest that peripheral immune cells in patients with active $\mathrm{CD}$ have higher SOD activity and $\mathrm{H}_{2} \mathrm{O}_{2}$ production (Beltran et al. 2010). It has also been shown that CGA may be responsible for inhibition of $\mathrm{H}_{2} \mathrm{O}_{2}$-induced apoptotic neuronal death (Kim et al. 2012). In addition, Feng et al. (2005) suggested that CGA may have protective properties against environmental carcinogen-induced carcinogenesis via upregulation of cellular anti-oxidant enzymes and suppression of ROS-mediated NF- $\mathrm{kB}$ activation. Another study showed that CGA was effective in protecting PC12 cells against methylmercury (MeHg)-induced damage through decrease of GPx activity and GSH levels ( $\mathrm{Li}$ et al. 2008). In our study, $\mathrm{H}_{2} \mathrm{O}_{2}$ levels were increased in mice with TNBS-induced colitis compared to control. However, topical administration of CGA did not reduce the amount of $\mathrm{H}_{2} \mathrm{O}_{2}$. The possible explanation is that the dose of CGA was insufficient to produce any effect on high levels of free radicals resulting from inflammatory processes in the mouse colon (Shi et al. 2011). We thus hypothesized that CGA may alter other anti-oxidative pathways, such as inhibition of lipid peroxidation, reduction of DNA damage, or increase of nitric oxide scavenging activity, which may need further confirmation.

\section{Conclusion}

CGA has anti-inflammatory properties in the mouse model of colitis through the reduction of neutrophil infiltration and inhibition of NF-KB-dependent pathways, but not the stimulation of the oxidative stress protection mechanism. Our results suggest that CGA has the potential to become a valuable supplement for the therapy of inflammatory GI diseases.
Acknowledgments This study was supported by bilateral cooperation between Poland and China, the Iuventus Plus program of the Polish Ministry of Science and Higher Education (0107/IP1/2013/72 to JF), and Medical University of Lodz (502-03/1-156-02/502-14-140 to M. Sałaga, 502-03/1-156-02/502-14-141 to M. Sobczak, and 503/1-156-04/ 503-01 to J. Fichna).

Conflict of interest The authors declare that they have no conflict of interest.

Ethical approval All applicable international, national, and/or institutional guidelines for the care and use of animals were followed. All procedures performed in studies involving animals were in accordance with the ethical standards of the institution or practice at which the studies were conducted.

Open Access This article is distributed under the terms of the Creative Commons Attribution License which permits any use, distribution, and reproduction in any medium, provided the original author(s) and the source are credited.

\section{References}

Atreya I, Atreya R, Neurath MF (2008) NF-kappaB in inflammatory bowel disease. J Intern Med 263:591-596

Babior BM (2000) Phagocytes and oxidative stress. Am J Med 109:3344

Beltran B, Nos P, Dasi F, Iborra M, Bastida G, Martinez M, O'Connor JE, Saez G, Moret I, Ponce J (2010) Mitochondrial dysfunction, persistent oxidative damage, and catalase inhibition in immune cells of naive and treated Crohn's disease. Inflamm Bowel Dis 16:76-86

Cadman E, Bostwick JR, Eichberg J (1979) Determination of protein by a modified Lowry procedure in the presence of some commonly used detergents. Anal Biochem 96:21-23

Del Rio D, Stalmach A, Calani L, Crozier A (2010) Bioavailability of coffee chlorogenic acids and green tea flavan-3-ols. Nutrients 2 : 820-833

di Paola PR, Esposito E, Mazzon E, Caminiti R, Toso RD, Pressi G, Cozzocrea S (2010) 3,5-Dicaffeoyl-4-malonylquinic acid reduced oxidative stress and inflammation in a experimental model of inflammatory bowel disease. Free Radic Res 44:74-89

Elson CO, Sartor RB, Tennyson GS, Riddell RH (1995) Experimental models of inflammatory bowel disease. Gastroenterology 109: 1344-1367

Feng R, Lu Y, Bowman LL, Qian Y, Castranova V, Ding M (2005) Inhibition of activator protein-1, NF-kappaB, and MAPKs and induction of phase 2 detoxifying enzyme activity by chlorogenic acid. J Biol Chem 280:27888-27895

Fichna J, Dicay M, Lewellyn K, Janecka A, Zjawiony JK, MacNaughton WK, Storr MA (2012) Salvinorin A has antiinflammatory and antinociceptive effects in experimental models of colitis in mice mediated by KOR and CB1 receptors. Inflamm Bowel Dis 18: $1137-1145$

Francisco V, Costa G, Figueirinha A, Marques C, Pereira P, Miguel NB, Celeste LM, Garcia-Rodriguez C, Teresa CM, Teresa BM (2013) Anti-inflammatory activity of Cymbopogon citratus leaves infusion via proteasome and nuclear factor-kappaB pathway inhibition: contribution of chlorogenic acid. J Ethnopharmacol 148:126-134

Hebeda CB, Bolonheis SM, Nakasato A, Belinati K, Souza PD, Gouvea DR, Lopes NP, Farsky SH (2011) Effects of chlorogenic acid on neutrophil locomotion functions in response to inflammatory stimulus. J Ethnopharmacol 135:261-269 
Hoesel B, Schmid JA (2013) The complexity of NF-kappaB signaling in inflammation and cancer. Mol Cancer 12:86

Hulme AC (1953) The isolation of chlorogenic acid from the apple fruit. Biochem J 53:337-340

Kim HR, Lee DM, Lee SH, Seong AR, Gin DW, Hwang JA, Park JH (2010) Chlorogenic acid suppresses pulmonary eosinophilia, IgE production, and Th2-type cytokine production in an ovalbumininduced allergic asthma: activation of STAT-6 and JNK is inhibited by chlorogenic acid. Int Immunopharmacol 10:1242-1248

Kim J, Lee S, Shim J, Kim HW, Kim J, Jang YJ, Yang H, Park J, Choi SH, Yoon JH, Lee KW, Lee HJ (2012) Caffeinated coffee, decaffeinated coffee, and the phenolic phytochemical chlorogenic acid up-regulate NQO1 expression and prevent $\mathrm{H}(2) \mathrm{O}(2)$-induced apoptosis in primary cortical neurons. Neurochem Int 60:466-474

Knutson CG, Mangerich A, Zeng Y, Raczynski AR, Liberman RG, Kang P, Ye W, Prestwich EG, Lu K, Wishnok JS, Korzenik JR, Wogan GN, Fox JG, Dedon PC, Tannenbaum SR (2013) Chemical and cytokine features of innate immunity characterize serum and tissue profiles in inflammatory bowel disease. Proc Natl Acad Sci U S A 110:2332-2341

Korzenik JR, Dieckgraefe BK, Valentine JF, Hausman DF, Gilbert MJ (2005) Sargramostim for active Crohn's disease. N Engl J Med 352: 2193-2201

Kucharzik T, Walsh SV, Chen J, Parkos CA, Nusrat A (2001) Neutrophil transmigration in inflammatory bowel disease is associated with differential expression of epithelial intercellular junction proteins. Am J Pathol 159:2001-2009

Lafay S, Gil-Izquierdo A, Manach C, Morand C, Besson C, Scalbert A (2006) Chlorogenic acid is absorbed in its intact form in the stomach of rats. J Nutr 136:1192-1197

Li Q, Verma IM (2002) NF-kappaB regulation in the immune system. Nat Rev Immunol 2:725-734

Li Y, Shi W, Li Y, Zhou Y, Hu X, Song C, Ma H, Wang C, Li Y (2008) Neuroprotective effects of chlorogenic acid against apoptosis of PC12 cells induced by methylmercury. Environ Toxicol Pharmacol 26:13-21

Li JJ, Jia GL, Wang J, Liang JQ, Yan L, Zhang ZY (2014a) Index components contents in honeysuckle change trend at different time in a day and different stubbles in a year. Zhongguo Zhong Yao Za Zhi 39:1225-1228

Li W, Tang Y, Qian Y, Shang E, Wang L, Zhang L, Su S, Duan JA (2014b) Comparative analysis of main aromatic acids and phthalides in Angelicae Sinensis Radix, Chuanxiong Rhizoma, and Fo-ShouSan by a validated UHPLC-TQ-MS/MS. J Pharm Biomed Anal 99: $45-50$

Molodecky NA, Soon IS, Rabi DM, Ghali WA, Ferris M, Chernoff G, Benchimol EI, Panaccione R, Ghosh S, Barkema HW, Kaplan GG (2012) Increasing incidence and prevalence of the inflammatory bowel diseases with time, based on systematic review. Gastroenterology 142:46-54

Ng SC, Tang W, Leong RW, Chen M, Ko Y, Studd C, Niewiadomski O, Bell S, Kamm MA, de Silva HJ, Kasturiratne A, Senanayake YU, Ooi CJ, Ling KL, Ong D, Goh KL, Hilmi I, Ouyang Q, Wang YF, Hu P, Zhu Z, Zeng Z, Wu K, Wang X, Xia B, Li J, Pisespongsa P, Manatsathit S, Aniwan S, Simadibrata M, Abdullah M, Tsang SW, Wong TC, Hui AJ, Chow CM, Yu HH, Li MF, Ng KK, Ching J, Wu JC, Chan FK, Sung JJ (2014) Environmental risk factors in inflammatory bowel disease: a population-based case-control study in Asia-Pacific. Gut

Podolsky DK (2002) Inflammatory bowel disease. N Engl J Med 347: 417-429

Reaves TA, Colgan SP, Selvaraj P, Pochet MM, Walsh S, Nusrat A, Liang TW, Madara JL, Parkos CA (2001) Neutrophil transepithelial migration: regulation at the apical epithelial surface by Fcmediated events. Am J Physiol Gastrointest Liver Physiol 280: 746-754

Ruifeng G, Yunhe F, Zhengkai W, Ershun Z, Yimeng L, Minjun Y, Xiaojing S, Zhengtao Y, Naisheng Z (2014) Chlorogenic acid attenuates lipopolysaccharide-induced mice mastitis by suppressing TLR4-mediated NF-kappaB signaling pathway. Eur J Pharmacol 729:54-58

Sałaga M, Mokrowiecka A, Zakrzewski PK, Cygankiewicz A, Leishman E, Sobczak M, Zatorski H, Małecka-Panas E, Kordek R, Storr M, Krajewska WM, Bradshaw HB, Fichna J (2013) Experimental colitis in mice is attenuated by changes in the levels of endocannabinoid metabolites induced by selective inhibition of fatty acid amide hydrolase (FAAH). J Crohn's Colitis 8:998-1009

Sałaga M, Lewandowska U, Sosnowska D, Zakrzewski PK, Cygankiewicz AI, Piechota-Polańczyk A, Sobczak M, Mosinska P, Chen C, Krajewska WM, Fichna J (2014a) Polyphenol extract from evening primrose pomace alleviates experimental colitis after intracolonic and oral administration in mice. NaunynSchmiedeberg's Arch Pharmacol 387:1069-1078

Sałaga M, Polepally PR, Zakrzewski PK, Cygankiewicz A, Sobczak M, Kordek R, Zjawiony JK, Krajewska WM, Fichna J (2014b) Novel orally available salvinorin A analog PR-38 protects against experimental colitis and reduces abdominal pain in mice by interaction with opioid and cannabinoid receptors. Biochem Pharmacol 92(4): 618-626

Shan J, Fu J, Zhao Z, Kong X, Huang H, Luo L, Yin Z (2009) Chlorogenic acid inhibits lipopolysaccharide-induced cyclooxygenase-2 expression in RAW264.7 cells through suppressing NFkappaB and JNK/AP- activation. Int Immunopharmacol 9:10421048

Shi XZ, Winston JH, Sarna SK (2011) Differential immune and genetic responses in rat models of Crohn's colitis and ulcerative colitis. Am J Physiol Gastrointest Liver Physiol 300:41-51

Stawinska M, Cygankiewicz A, Trzcinski R, Mik M, Dziki A, Krajewska WM (2008) Alterations of Chk1 and Chk2 expression in colon cancer. Int J Color Dis 23:1243-1249

Storr MA, Keenan CM, Zhang H, Patel KD, Makriyannis A, Sharkey KA (2009) Activation of the cannabinoid 2 receptor (CB2) protects against experimental colitis. Inflamm Bowel Dis 15:1678-1685

Sun P, Zhou K, Wang S, Li P, Chen S, Lin G, Zhao Y, Wang T (2013) Involvement of MAPK/NF-kappaB signaling in the activation of the cholinergic anti-inflammatory pathway in experimental colitis by chronic vagus nerve stimulation. PLoS One 8:e69424

Suzuki A, Yamamoto N, Jokura H, Yamamoto M, Fujii A, Tokimitsu I, Saito I (2006) Chlorogenic acid attenuates hypertension and improves endothelial function in spontaneously hypertensive rats. $\mathbf{J}$ Hypertens 24:1065-1073

Umezawa K (2011) Possible role of peritoneal NF-kappaB in peripheral inflammation and cancer: lessons from the inhibitor DHMEQ. Biomed Pharmacother 65:252-259

Valko M, Morris H, Mazur M, Rapta P, Bilton RF (2001) Oxygen free radical generating mechanisms in the colon: do the semiquinones of vitamin K play a role in the aetiology of colon cancer? Biochim Biophys Acta 1527:161-166

Valko M, Leibfritz D, Moncol J, Cronin MT, Mazur M, Telser J (2007) Free radicals and antioxidants in normal physiological functions and human disease. Int J Biochem Cell Biol 39:44-84

Zhang YZ, Li YY (2014) Inflammatory bowel disease: pathogenesis. World J Gastroenterol 20:91-99

Zhang X, Huang H, Yang T, Ye Y, Shan J, Yin Z, Luo L (2010) Chlorogenic acid protects mice against lipopolysaccharide-induced acute lung injury. Injury 41:746-752 